\title{
Kebijakan Hukum terhadap Tindak Pidana Penangkapan Ikan Secara Ilegal di Perairan Indonesia
}

\author{
Eko Budi $\mathbf{S}^{1}$ \\ Fakultas Hukum Universitas Batanghari Jambi, Jl. Slamet Riyadi Broni - Jambi \\ Email: ekobudi1999@yahoo.co.id
}

\begin{abstract}
Abstrak
Kebijakan hukum terhadap pelaku tindak pidana perikanan pada dasarnya diarahkan pada pertanggungjawaban pelaku tindak pidana perikanan (illegal fishing). Dampak illegal fishing menyebabkan keterpurukan ekonomi nasional dan meningkatnya permasalahan sosial di masyarakat perikanan Indonesia. Undang-Undang RI No. 45 Tahun 2009 tentang perubahan atas Undang-Undang RI No. 31 Tahun 2004 tentang Perikanan telah mengatur tentang tindak pidana (delik) di bidang perikanan yang dibagi menjadi 2 kategori, yaitu kategori pelanggaran dan kejahatan. Efektifitas penegakan hukum masih kurang dikarenakan masih ada beberapa hambatan antara lain faktor substansi, struktural, sarana prasarana pendukung, masyarakat dan budaya masyarakat itu sendiri. Pemerintah Indonesia telah melakukan upaya dalam meminimalkan hambatan tersebut melalui beberapa strategi dalam rangka memberantas praktik ilegal fishing di perairan Indonesia.
\end{abstract}

Kata kunci : Kebijakan hukum, tindak pidana, illegal fishing.

\begin{abstract}
Legal policy against fisheries offenders is basically directed at the accountability of fisheries offenders (illegal fishing). The impact of illegal fishing causes a deterioration in the national economy and increasing social problems in the Indonesian fisheries community. The Republic of Indonesia Law Number. 45 of 2009 concerning amendments to the Republic of Indonesia Law Number. 31 of 2004 concerning Fisheries has regulated criminal acts (offenses) in the field of fisheries which are divided into 2 categories, namely the category of violations and crimes. The effectiveness of law enforcement is still lacking because there are still a number of obstacles, including the substance, structural, supporting infrastructure, the community and the culture of the community itself. The Indonesian government has made efforts to minimize these obstacles through several strategies in order to eradicate the practice of illegal fishing in Indonesian waters.
\end{abstract}

Keywords: Legal policy, criminal, illegal fishing.

\section{PENDAHULUAN}

Negara Kesatuan Republik Indonesia adalah merupakan Negara Kepulauan, yang sebagian besar wilayahnya terdiri dari wilayah perairan (laut) yang sangat luas dengan potensi perikanan yang sangat besar dan beragam. Potensi perikanan yang dimiliki merupakan kekayaan negara dan sebagai potensi ekonomi yang dapat dimanfaatkan untuk masa depan bangsa, sebagai tulang punggung pembangunan nasional. Diantara sekian banyak masalah ekonomi ilegal, praktik pencurian ikan atau IUU (Illegal, Unregulated and Unreported fishing practices) oleh nelayan-nelayan menggunakan armada kapal ikan asing adalah yang paling banyak merugikan negara. Luasnya wilayah perairan Indonesia, dan lemahnya pengawasan pihak berwenang terhadap kegiatan perikanan, seringkali dimanfaatkan nelayan asing untuk melakukan illegal fishing di laut teritorial Indonesia. Sebagian pelaku memang dibawa ke proses hukum. Namun, penjatuhan sanksi yang dijatuhkan kepada pelaku illegal fishing masih terbilang rendah.

Indonesia memiliki perairan seluas $3.273 .810 \mathrm{~km}^{2}$ yang menjadi habitat paling ideal bagi satwa dan biota laut untuk hidup dan berkembang biak seperti ikan, terumbu karang, lobster, rumput laut dan lainnya. Dengan garis pantai $95.181 \mathrm{~km}^{2}$ dan merupakan terpanjang kedua di dunia setelah Kanada, Indonesia memiliki potensi ekonomi laut senilai US\$ 1,2 triliun per tahun, namun sayang selama puluhan tahun perairan luas nan kaya ikan itu dicuri menggunakan kapal-kapal asing penangkap ikan. Pada tahun 2017 data ekspor sektor perikanan Indonesia hanya senilai US\$ 3,34 miliar, kalah jauh dibandingkan Vietnam yang pada tahun sama senilai US\$ 25 miliar, padahal dalam hal luas perairan dan panjang garis pantai, Vietnam

${ }^{1}$ Dosen pada Fakultas Hukum Universitas Batanghari Jambi. 
tidak ada apa-apanya dibandingkan Indonesia, ${ }^{2}$ sedangkan pada tahun 2014 mengalami kenaikan menjadi US\$ 3,1 miliar. Lalu pada kuartal I 2015 nilai ekspor perikanan sudah menembus US\$ 906,77 juta. ${ }^{3}$ Namun, menurut data dari Koalisi Rakyat untuk Keadilan Perikanan sejak Januari sampai Agustus 2015 jumlah pencurian ikan menggunakan kapal-kapal nelayan asing diperkirakan telah merugikan negara Rp. 101 triliun. $^{4}$

Dalam pidato pelantikannya sebagai Presiden Republik Indonesia, Joko Widodo mengajak semua kalangan bekerja keras mengembalikan Indonesia sebagai negara maritim dan memandang samudera, laut, selat dan teluk sebagai masa depan peradaban Indonesia. Laut adalah masa depan Indonesia sekaligus bagian dari peradaban. Jika tidak tegas dari sekarang, pencurian ikan akan semakin menjadi-jadi dan kekayaan ikan tinggal cerita.

Pemberantasan illegal fishing dengan menggunakan aturan hukum UU RI No. 31 tahun 2004 yang telah dirubah menjadi UU RI No. 34 tahun 2009 tentang perikanan diharapkan mampu memberantas mafia illegal fishing dalam rangka menyelamatkan kekayaan negara di sektor perikanan, namun kenyataannya jauh panggang dari api. Pemberantasan illegal fishing menggunakan instrumen tersebut telah mengatur pemidanaan terhadap para pelakunya. Pada dasarnya pemidanaan dapat diartikan sebagai penjatuhan pidana oleh hakim yang merupakan konkritisasi atau realisasi dari ketentuan pidana dalam undang-undang yang merupakan sesuatu yang abstrak. Pemidanaan adalah hal yang berkenaan dengan hukuman seperti tujuan atau maksud dijatuhkannya pidana. ${ }^{5}$ Dengan banyaknya kasus pelanggaran penangkapan ikan secara illegal (illegal fishing) yang dilakukan oleh kapal nelayan baik berbendera Indonesia maupun kapal berbendera asing di perairan Indonesia maka pemerintah Indonesia harus melakukan upaya penegakan hukum untuk mencegah dan menanggulangi tindak pidana penangkapan ikan secara illegal tersebut.

Ada beberapa isu penting dalam penegakan hukum perikanan saat ini. Isu tersebut tidak hanya dalam substansi hukumnya tetapi juga dalam bekerjanya lembaga penegak hukumnya, diantaranya adalah dalam proses pembuktian pelaku-pelaku yang berada di belakang illegal fishing tersebut memerlukan waktu yang cukup lama daripada tindak pidana umum serta sangat dibutuhkan ketelitian dalam proses penanganannya, sehingga untuk pengungkapan yang benar-benar sampai pelaku utamanya masih sulit ditembus. Belum diaturnya mekanisme proses untuk mengakses alat-alat bukti seperti akses informasi pada Bank atau ketentuan yang memerintahkan kepada Bank untuk memblokir rekening tersangka yang diduga sebagai pelaku tindak pidana. Sementara itu ruang lingkup tindak pidana yang masih sempit yang diatur dalam Undang-undang Perikanan belum meliputi tindak pidana korporasi, tindak pidana penyertaan dan tindak pidana pembiaran (ommission).

\section{METODE PENULISAN}

Metode penulisan yang digunakan adalah metode penulisan deduktif yaitu dengan cara pemaparan secara umum untuk mendapatkan kesimpulan secara khusus, tipe yang digunakan adalah yuridis normatif yang bersifat deskriptif analitik, untuk memperoleh gambaran secara menyeluruh dan mendalam serta melakukan analisis terhadap permasalahan yang dibahas.

Untuk menjawab permasalahan maka dilakukan pengumpulan bahan hukum melalui studi kepustakaan berupa bahan hukum primer, sekunder dan tersier, bahan-bahan tersebut kemudian diinventarisasi dan diidentifikasi, teknis analisis dilakukan secara interpretasi, yaitu bahan hukum diinterpretasikan dan dijabarkan dengan mendasarkan pada suatu norma dan pendekatan konsep kriminologi, sedangkan penarikan kesimpulan dilakukan dengan menggunakan metode penalaran secara deduktif.

${ }^{2}$ https://lingkunganitats.wordpress.com/2014/12/25/kasus-pencurian-ikan-di-wilayah-indonesia/\#more-1407, diakses tanggal 2 Januari 2018.

${ }^{3}$ http://www.cnnindonesia.com/ekonomi/20150518201340-92-54026/ekspor-perikanan-naik-signifikan/, diakses tanggal 2 Januari 2018.

${ }^{4}$ http://www.medanbisnisdaily.com/news/read/2014/11/11/128705/memberantas-ganasnya-pencurian-ikan-di-perairanindonesia/ diakses tanggal 2 Januari 2018.

${ }^{5}$ Adami Chazawi, Pelajaran Hukum Pidana Stelsel Pidana, Tindak Pidana, Teori-Teori Pemidanaan Dan Batas Berlakunya Hukum Pidana, PT. Rajagrafindo Persada, Jakarta, 2002, hal. 151. 


\section{HASIL DAN PEMBAHASAN \\ Definisi illegal fishing}

Yang dimaksud dengan IUU fishing (Illegal Unreported and unregulated) adalah kegiatan penangkapan ikan yang illegal/tidak sah, unreported/tidak dilaporkan dan unregulated/tidak sesuai aturan. Berdasarkan International Plan of Action to Prevent, Deter and Eliminate IUU Fishing (IPOA-IUU Fishing) tahun 2001, yang dimaksud kegiatan perikanan yang dianggap melakukan illegal fishing antara lain:

Kegiatan perikanan oleh orang atau kapal asing di perairan yang menjadi yurisdiksi suatu negara, tanpa izin dari negara tersebut atau bertentangan dengan hukum dan peraturan perundang-undangan. Kegiatan perikanan yang dilakukan oleh kapal yang mengibarkan bendera suatu negara yang menjadi anggota dari satu organisasi pengelolaan perikanan regional, akan tetapi dilakukan melalui cara yang bertentangan dengan pengaturan mengenai pengelolaan dan konservasi sumber daya yang diadopsi oleh organisasi tersebut, dimana ketentuan tersebut mengikat bagi negara-negara yang menjadi anggotanya, ataupun bertentangan dengan hukum Internasional lainnya yang relevan. ${ }^{6}$

Sedangkan yang dimaksud Unreported Fishing adalah kegiatan perikanan yang tidak dilaporkan atau dilaporkan secara tidak benar, kepada otoritas nasional yang berwenang, yang bertentangan dengan hukum dan peraturan perundang-undangan dan kegiatan perikanan yang dilakukan yang belum dilaporkan atau dilaporkan secara tidak benar, yang bertentangan dengan prosedur pelaporan dari organisasi tersebut.

Jenis-jenis kegiatan perikanan yang tidak dilaporkan, antara lain: pelaporan data hasil tangkapan, sea transhipment tanpa didata/dilaporkan kepada aparat yang berwenang; tidak melaporkan hasil tangkapannya, untuk menghindari pembayaran pungutan atas usaha yang dilakukan; kapal penangkap ikan dan kapal pengangkut ikan tidak melapor di pelabuhan pangkalan kapal sesuai izin yang diberikan dan kapal penangkap ikan langsung dari laut membawa ikan hasil tangkapan ke luar negeri. ${ }^{7}$

Adapun kegiatan perikanan yang Unregulated Fishing adalah kegiatan perikanan yang dilakukan di area kompetensi yang relevan, dilakukan oleh kapal tanpa kebangsaan, atau oleh kapal yang mengibarkan bendera suatu negara yang tidak menjadi anggota dari organisasi tersebut, atau oleh perusahaan perikanan, yang dilakukan melalui cara yang bertentangan dengan pengaturan konservasi dan pengelolaan organisasi tersebut; kegiatan perikanan yang dilakukan di wilayah perairan atau untuk sediaan ikan dimana belum ada pengaturan konservasi dan pengelolaan yang dapat diterapkan, yang dilakukan melalui cara yang bertentangan dengan tanggung jawab negara untuk melakukan konservasi dan pengelolaan sumber daya alam hayati laut sesuai dengan ketentuan hukum internasional. ${ }^{8}$ Kegiatan IUU Fishing ini mencakup pelanggaran terkait pengelolaan dan pelestarian sumberdaya perikanan di perairan nasional maupun internasional.

\section{Faktor-faktor penyebab dan dampak illegal fishing}

Secara garis besar faktor-faktor penyebab tersebut dapat dikategorikan menjadi 7 (tujuh) faktor, antara lain: Pertama, Kebutuhan ikan dunia (demand) meningkat, disisi lain pasokan ikan dunia menurun, terjadi overdemand terutama jenis ikan dari laut seperti Tuna. Kedua, Disparitas harga ikan segar utuh (whole fish) di negara lain dibandingkan di Indonesia cukup tinggi sehingga membuat masih adanya surplus pendapatan. Ketiga, Fishing ground di negara-negara lain sudah mulai habis, sementara di Indonesia masih menjanjikan, padahal mereka harus mempertahankan pasokan ikan untuk konsumsi mereka dan harus mempertahankan produksi pengolahan di negara tersebut tetap bertahan. Keempat, Laut Indonesia sangat luas dan terbuka, di sisi lain kemampuan pengawasan khususnya armada pengawasan nasional (kapal patroli/pengawas) masih sangat terbatas dibandingkan kebutuhan untuk mengawasai daerah rawan. Kelima, Sistem pengelolaan

${ }^{6}$ http://www.djpt.kkp.go.id/index.php/profil/c/15/Apa-yang-dimaksud-IUU-fishing/?category_id=12 diakses tanggal 2 Januari 2018.

${ }^{7}$ Ibid.

${ }^{8}$ Ibid. 
perikanan dalam bentuk sistem perizinan saat ini bersifat terbuka (open acces), pembatasannya hanya terbatas pada alat tangkap (input restriction). Keenam, Masih terbatasnya sarana dan prasarana pengawasan serta sumber daya manusia pengawasan khususnya dari sisi kuantitas. Sebagai gambaran, sampai dengan tahun ini baru terdapat 578 Penyidik Perikanan (PPNS Perikanan) dan 340 ABK (Anak Buah Kapal) Kapal Pengawas Perikanan. Jumlah tersebut, tentunya sangat belum sebanding dengan cakupan luas wilayah laut yang harus diawasi. Hal ini, lebih diperparah dengan keterbatasan sarana dan prasarana pengawasan. Ketujuh, Persepsi dan langkah kerjasama aparat penegak hukum dalam penanganan perkara tindak pidana perikanan masih belum solid, terutama dalam hal pemahaman tindakan hukum, dan komitmen operasi kapal pengawas di ZEE.

Kegiatan Illegal Fishing di WPP-RI telah mengakibatkan kerugian yang besar bagi Indonesia. Overfishing, overcapacity, ancaman terhadap kelestarian sumberdaya ikan, iklim usaha perikanan yang tidak kondusif, melemahnya daya saing perusahaan dan kelemahan nelayan merupakan dampak nyata dari kegiatan IUU fishing. Kerugian lain yang tidak dapat di nilai secara materil namun sangat terkait dengan harga diri bangsa, adalah rusaknya citra Indonesia pada kancah International karena dianggap tidak mampu untuk mengelola perikanannya dengan baik. Untuk dapat mengetahui, kerugian materil yang diakibatkan oleh Illegal fishing perlu ditetapkan angka asumsi dasar antara lain: diperkirakan jumlah kapal asing dan eks asing yang melakukan IUU fishing sekitar 1000 kapal, ikan yang dicuri dari kegiatan IUU fishing dan dibuang (discarded) sebesar 25\% dari stok (estimasi FAO, 2001). Dengan asumsi tersebut, jika MSY (maximum sustainable yield $=$ tangkapan lestari maksimum) $\mathrm{ikan}=6,4$ juta ton/th, maka yang hilang di curi dan dibuang sekitar 1,6 juta ton/th. Jika harga jual ikan di luar negeri rata-rata $2 \mathrm{USD} / \mathrm{Kg}$, maka kerugian per tahun bisa mencapai Rp 30 trilyun. Negara-negara yang (warganya) mencuri ikan di wilayah laut Indonesia antara lain: Thailand, Filipina, Vietnam, Malaysia, RRC, dan Taiwan yang potensi sumber daya ikan lautnya jauh lebih kecil. ${ }^{9}$

Maraknya perikanan ilegal di perairan Indonesia berdampak terhadap stok ikan nasional dan global. Hal ini juga menyebabkan keterpurukan ekonomi nasional dan meningkatnya permasalahan sosial di masyarakat perikanan Indonesia. Sedikitnya terdapat sepuluh masalah pokok dari aktivitas perikanan ilegal yang telah memberi dampak serius bagi Indonesia. ${ }^{10}$ Pertama, perikanan ilegal di perairan Indonesia akan mengancam kelestarian stok ikan nasional bahkan dunia. Kedua, perikanan ilegal di perairan Indonesia akan mengurangi kontribusi perikanan tangkap di wilayah ZEEI atau laut lepas kepada ekonomi nasional (PDB). Ketiga, perikanan illegal mendorong ke arah penurunan tenaga kerja pada sektor perikanan nasional, seperti usaha pengumpulan dan pengolahan ikan. Keempat, perikanan ilegal akan mengurangi peran tempat pendaratan ikan nasional (pelabuhan perikanan nasional) dan penerimaan uang pandu pelabuhan. Kelima, perikanan ilegal akan mengurangi pendapatan dari jasa dan pajak dari operasi yang sah. Keenam, baik secara langsung maupun tidak langsung, multiplier effects dari perikanan ilegal memiliki hubungan dengan penangkapan ikan nasional. Ketujuh, perikanan ilegal akan berdampak pada kerusakan ekosistem, akibat hilangnya nilai dari kawasan pantai. Kedelapan, perikanan ilegal akan meningkatkan konflik dengan armada nelayan tradisional. Kesembilan, perikanan ilegal berdampak negatif pada stok ikan dan ketersediaan ikan, yang merupakan sumber protein penting bagi Indonesia. Kesepuluh, perikanan ilegal akan berdampak negative pada isu kesetaraan gender dalam penangkapan ikan dan pengolahan serta pemasaran hasil penangkapan ikan. Fakta di beberapa daerah menunjukkan bahwa istri nelayan memiliki peranan penting dalam aktivitas penangkapan ikan di pantai dan pengolahan hasil tangkapan, termasuk untuk urusan pemasaran hasil perikanan.

\section{Kebijakan hukum terhadap tindak pidana illegal fishing}

Penegakan hukum terhadap tindak pidana illegal fishing telah menjadi isu publik yang saat ini sering diperbincangkan oleh masyarakat sejak adanya Satgas 155 "Satgas Pemberantasan Illegal Fishing" sampai dengan sekarang. ${ }^{11}$ Data menunjukkan pada pertengahan tahun 2017 sebanyak 95 kapal nelayan ilegal telah

\footnotetext{
${ }^{9}$ Ibid.

${ }^{10}$ http://ikanmania25.blogspot.com/2011/11/illegal-fishing.html, diakses tanggal 3 Januari 2018.

${ }^{11} \mathrm{https} / / /$ bisnis.tempo.co/read/894780/sepanjang-2017-95-kapal-illegal-ditangkap-menteri-susi/full\& view=ok, diunduh tanggal 3 Agustus 2018.
} 
ditangkap, terdiri dari 23 kapal perikanan Indonesia (KII) dan 72 kapal perikanan asing (KIA). Jumlah tersebut yang ditangkap PSDKP-KKP 53 kapal, TNI Angkatan Laut 195 kapal, Polri 24 kapal. Hasilnya, akhir tahun 2017 saja 367 kapal illegal fishing berhasil diamankan. Sejak 2014 hingga sekarang, tercatat 317 kapal ilegal telah ditenggelamkan setelah inkrah. Beberapa kapal nelayan yang kerap nakal untuk masuk perairan Indonesia tanpa izin yakni Vietnam (144 kapal), Filipina (76 kapal), Malaysia (50 kapal), Thailand (21 kapal), Papua Nugini (2 kapal), Cina (1 kapal), serta Belize (1 kapal). ${ }^{12}$

Secara subtansial, perubahan yang signifikan pada Undang-Undang RI No. 45 tahun 2009 dibandingkan dengan Undang-Undang RI No. 31 tahun 2004 yang terdahulu, adalah penekanan pada ketentuan sanksi pidana berat terhadap kapal asing yang melakukan tindak pidana pencurian ikan di Zona Ekonomi Eksklusif Indonesia. ${ }^{13}$

Beberapa hal yang dapat dicermati tentang perubahan-perubahan substansial antara Undang-Undang Nomor 31 Tahun 2004 dengan Undang-Undang Nomor 45 Tahun 2009 antara lain:

a. Hal pembatasan penangkapan kapal penangkap ikan berbendera asing tidak diperbolehkan menangkap ikan di Zona Ekonomi Eksklusif Indonesia Wilayah Pengelolaan Perikanan Republik Indonesia tanpa memiliki Surat Ijin Penangkapan Ikan (SIPI) yang dikeluarkan oleh Pemerintah Indonesia.

b. Zona Ekonomi Eksklusif Indonesia (ZEEI). Undang-Undang Nomor 31 Tahun 2004 tentang Perikanan pasal 93 tidak menyebutkan secara jelas mengenai Zona Ekonomi Eksklusif Indonesia (ZEEI), melainkan Wilayah Pengelolaan Perikanan Republik Indonesia. Melalui Undang-Undang RI No. 45 tahun 2009, penyebutan Zona Ekonomi Eksklusif Indonesia sudah sangat tegas dan jelas. Penegasan itu dapat dilihat pada Bab XV Ketentuan Pidana Pasal 93 ayat (2) menyatakan, "Setiap orang yang memiliki dan/atau mengoperasikan kapal penangkap ikan berbendera asing melakukan penangkapan ikan di ZEEI yang tidak memiliki SIPI sebagaimana dimaksud dalam Pasal 27 ayat (2), dipidana dengan pidana penjara paling lama 6 (enam) tahun dan denda paling banyak Rp. 20.000.000.000,- (dua puluh milyar rupiah).

c. Hal Kewenangan Penyelidikan dan Penyidikan yang di emban TNI-AL dan Pegawai Negeri Sipil Kementerian Kelautan dan Perikanan. Kewenangan besar bagi TNI-AL dan Penyidik Pegawai Negeri Sipil Kementerian Kelautan dan Perikanan yang diberikan Undang-Undang RI No. 45 tahun 2009 untuk mencegah dan memberantas pencurian ikan di Zona Ekonomi Eksklusif Indonesia (ZEEI) perairan Wilayah Pengelolaan Perikanan Republik Indonesia merupakan salah satunya tugas berat yang harus dilaksanakan. Dalam melaksanakan fungsi dan tugasnya, penyidik dan pengawas perikanan dapat melakukan tindakan khusus berupa pembakaran dan atau penenggelaman kapal perikanan yang berbendera asing berdasarkan bukti permulaan yang cukup.

d. Putusan perampasan benda dan/atau alat yang dipergunakan dalam dan/atau yang dihasilkan dari Tindak Pidana Pencurian Ikan. Pasal 104 ayat (2) Undang-Undang Nomor 45 Tahun 2009 tentang perubahan atas Undang-Undang Nomor 31 Tahun 2004 tentang Perikanan digunakan untuk menempatkan benda dan/atau alat yang dipergunakan dalam dan/atau yang dihasilkan dari tindak pidana pencurian ikan menjadi rampasan melalui putusan pengadilan.

e. Peran serta masyarakat diperlukan. Selain TNI-AL dan Penyidik Pegawai Negeri Sipil Kementerian Kelautan dan Perikanan dan Penegak Hukum lainnya, Undang-Undang Nomor 45 Tahun 2009 tentang perubahan atas Undang-Undang Nomor 31 Tahun 2004 tentang Perikanan, juga diikutsertakan masyarakat untuk berperan aktif dalam upaya pencegahan dan pemberantasan tindak pidana pencurian ikan di Zona Ekonomi Eksklusif Indonesia.

f. Tidak mementingkan unsur kesengajaan. Tindak pidana pencurian ikan di perairan Zona Ekonomi Eksklusif Indonesia "setiap orang yang memiliki dan/atau mengoperasikan" dalam beberapa pasal Undang-Undang Nomor 45 Tahun 2009 tentang perubahan atas Undang-Undang Nomor 31 Tahun 2004 tentang Perikanan dengan tidak memperdulikan unsur kesengajaan, dapat menjerat orang-orang yang memang sebenarnya tidak mempunyai niat melakukan tindak pidana pencurian ikan di Zona Ekonomi Eksklusif Indonesia.

g. Penggunaan sistem pidana, penggunaan sistem pidana penjara terhadap pelaku tindak pidana pencurian ikan oleh nelayan asing di Zona Ekonomi Eksklusif Indonesia (ZEEI) Wilayah Pengelolaan Perikanan

\footnotetext{
${ }^{12}$ Ibid.

${ }^{13}$ Supriadi, Hukum Perikanan Di Indonesia, Sinar Grafika, Jakarta, 2011, hal. 462.
} 
Republik Indonesia tidak diberlakukan. Penahanan pun tidak boleh dilakukan oleh penyidik. Ketika ditangkap di Tempat Kejadian Perkara, selanjutnya tersangka di bawa untuk diproses dengan membuat Berita Acara Pemeriksaan (BAP). Setelah selesai diperiksa, tersangka harus secepatnya dipulangkan ke negara asalnya tanpa ditahan terlebih dahulu.

Persamaan hukuman bagi percobaan dan tindak pidana sesuai Undang-Undang RI No. 45 tahun 2009 tentang perubahan atas Undang-Undang RI No. 31 tahun 2004 tentang Perikanan menyamakan hukuman pidana bagi pelaku tindak pidana selesai dengan pelaku tindak pidana percobaan. Tindak pidana pencurian ikan di Zona Ekonomi Eksklusif Indonesia (ZEEI) adalah suatu kejahatan karena perbuatan tersebut memiliki efek yang sangat besar yaitu merugikan Negara lebih kurang 30 trilyun rupiah per tahun.

Dari ketentuan pidana yang diatur dalam Bab XV Undang-Undang Nomor 45 Tahun 2009 tentang perubahan Undang-Undang Nomor 31 Tahun 2004 tentang Perikanan dapat dikelompokkan dari segi bentuk perbuatannya yaitu kejahatan dan pelanggaran. 1) Bentuk perbuatan yang dikategorikan kejahatan sebagaimana diatur dalam Pasal, 84, 85, 86, 88, 91, 92, 93, 94, dan 94A. 2) Bentuk perbuatan yang dikategorikan Pelanggaran sebagaimana diatur dalam Pasal, 87, 89, 90, 95, 96, 97, 98, 99, 100, 100A, 100B, 100C, dan 100D. Klasifikasi kejahatan dan pelanggaran dalam tindak pidana perikanan tersebut di atas telah sesuai dengan rumusan hukum pidana. ${ }^{14}$ Adapun perumusannya antara lain: a) Hukum Pidana adalah bagian dari keseluruhan hukum yang berlaku di suatu Negara. b) Perbuatan yang oleh hukum pidana dilarang dan diancam dengan pidana. c) Hukum pidana menentukan perbuatan mana yang dipandang sebagai perbuatan pidana. d) Barang siapa melakukan perbuatan pidana diancam dengan pidana. e) Hukum pidana mengatur tentang pertanggungjawaban hukum pidana (criminal liability/ criminal responsibility). f) Beberapa pendapat tentang pengertian hukum pidana. g) Hal-hal yang perlu ditegaskan sehubungan pengertian kita kepada hukum pidana. Berdasarkan rumusan tersebut, dalam tindak pidana perikanan dapat dengan jelas terlihat apakah itu berupa kejahatan ataupun pelanggaran yang dilakukan oleh pelaku tindak pidana pencurian ikan dan pidana apa yang akan diberikan kepada pelanggar peraturan perikanan yang ada.

Dalam pemidanaan terhadap pelaku tindak pidana perikanan harus dapat dipahami lebih mendalam dan harus diketahui dasar dari pemidanaan tersebut. Sistem pidana dan pemidanaan pada aliran klasik sangat menekankan pemidanaan terhadap perbuatan, bukan pada pelakunya. Artinya penetapan sanksi dalam undang-undang tidak dipakai sistem peringanan atau pemberatan yang berhubungan dengan faktor usia, keadaan jiwa si pelaku, kejahatan-kejahatan yang dilakukan terdahulu maupun keadaan-keadaan khusus dari perbuatan/kejahatan yang dilakukan. ${ }^{15}$ Aliran modern yang mencari sebab kejahatan dengan memakai metode ilmu alam dan bermaksud untuk langsung mendekati atau mempengaruhi penjahat secara positif sejauh dia masih dapat diperbaiki. Karenanya aliran ini bertitik tolak dari pandangan determinisme dan menghendaki adanya individualism pidana yang bertujuan mengadakan resosialisasi terhadap pelaku kejahatan.

Dalam hal Pembuktian, mengenai masalah pembuktian yang dianut oleh hukum pidana Indonesia adalah sistem negatif (negatif wettelijke stelsel) yang merupakan gabungan dari sistem bebas dengan sistem positif. Dalam sistem negatif Hakim hanya boleh menjatuhkan pidana terhadap terdakwa apabila berdasarkan bukti-bukti yang sah menurut hukum sehingga Hakim mempunyai keyakinan bahwa terdakwalah yang telah bersalah melakukan tindak pidana. Hal ini berdasarkan ketentuan Pasal 183 UU No. 8 Tahun 1981 KUHAP, yang menyatakan bahwa "Hakim tidak boleh menjatuhkan pidana kepada seorang kecuali apabila dengan sekurang-kurangnya dua alat bukti yang sah ia memperoleh keyakinan bahwa suatu tindak pidana benar-benar terjadi dan bahwa terdakwalah yang bersalah melakukannya".

Alat bukti utama yang dapat dijadikan dasar tuntutan dalam tindak pidana illegal fishing adalah keterangan saksi ahli untuk menjelaskan keadaan laut ataupun akibat dari penangkapan ikan secara ilegal yang disebabkan oleh kajahatan oleh para pelaku illegal fishing, proses ini juga sangat memerlukan waktu yang cukup lama dari tindak pidana umum serta sangat dibutuhkan ketelitian dalam proses penanganannya.

\footnotetext{
${ }^{14}$ Djoko Prakoso, Pembaharuan Hukum Pidana di Indonesia, Penerbit Liberty, Yogyakarta, 2000, hal. 19.

${ }^{15}$ Barda Nawawi Arief, Kapita Selekta Hukum Pidana Tentang Sistem Peradilan Terpadu, Badan Penerbit Universitas Diponegoro, Semarang, 2006, hal. 62.
} 
Pembuktian terhadap tindak pidana illegal fishing yang masih mengacu pada KUHAP seperti tersebut diatas, adalah merupakan kewajiban penyidik dan penuntut umum untuk membuktikan sangkaannya terhadap tersangka, kemudian alat-alat bukti yang juga mengacu pada KUHAP seperti halnya tindak pidana biasa, sangat sulit untuk menjerat pelaku-pelaku yang berada di belakang kasus tersebut. Belum diaturnya mekanisme proses untuk mengakses alat-alat bukti seperti akses informasi pada bank atau ketentuan yang memerintahkan kepada bank untuk meblokir rekening tersangka yang diduga sebagai pelaku tindak pidana.

Ruang lingkup tindak pidana yang masih sempit yang diatur dalam Undang-undang Nomor 31 Tahun 2004 dan perubahannya Undang-Undang Nomor 45 Tahun 2009 tentang Perikanan belum meliputi tindak pidana korporasi, tindak pidana penyertaan dan tindak pidana pembiaran (ommission). Tindak pidana pembiaraan atau (ommission) adalah terutama yang dilakukan oleh pejabat yang memiliki kewenangan dalam masalah penanggulangan illegal fishing.

\section{Hambatan}

Suatu perbuatan yang dikategorikan sebagai tindak pidana pada dasarnya merupakan perbuatan yang dicela dan dilarang untuk dilakukan sebab dapat merugikan kepentingan orang lain maupun kepentingan umum. Dengan demikian suatu perbuatan yang dikategorikan sebagai tindak pidana adalah apabila perbuatan tersebut dilarang oleh Undang-Undang dan diancam dengan pidana. Oleh karena itu segala perbuatan ataupun aktivitas yang dilakukan secara illegal diwilayah perairan laut Indonesia yang dengan tegas dinyatakan sebagai keharusan atau larangan oleh undang-undang dan harus diberantas karena merupakan suatu tindak pidana. Dalam rangka pemberantasan illegal fishing oleh nelayan asing cara yang lebih efektif adalah dengan penagakan hukum.

Mengenai faktor-faktor yang menghambat penegakan hukum meliputi hukum itu sendiri (sustansi hukum), aparat hukum (struktural), sarana prasarana, masyarakat dan kebudayaan. ${ }^{16}$ Faktor penghambat tersebut antara lain: Pertama, Hambatan yang berkaitan dengan substansi hukum. Sebagaimana dijelaskan dalam UU RI No. 31 tahun 2004 yang telah dirubah menjadi UU RI No. 34 tahun 2009 tentang perikanan secara yuridis formal terdapat tiga instansi yang diberi wewenang melakukan penyidikan terhadap tindak pidana perikanan diwilayah perairan laut Indonesia yakni Perwira TNI Angkatan Laut, Penyidik Kepolisian Negara Republik Indonesia, dan Penyidik Pegawai Negeri Sipil Perikanan. Meskipun demikian undangundang tersebut tidak mengatur secara tegas dan jelas pembagian kewenangan, serta pengaturan mekanisme kerja yang pasti, sehingga ketiga instansi tersebut dapat menyatakan berwenang dalam penegakan hukum tanpa adanya keterpaduan sistem dalam pelaksanaannya. Pengaturan yang demikian ini dapat menimbulkan kerawanan adanya perbedaan penafsiran peraturan perundang-undangan dan perbedaan pola penegakan hukum diantara sesama aparat, bahkan timbul kekhawatiran akan adanya ketidak harmonisan atau gesekan antar aparat dalam pelaksanaan pemberantasan illegal fishing. ${ }^{17}$ Keadaan ini sangat potensial untuk menimbulkan konflik kewenangan dalam penegakan hukum. Padahal Konflik kewenangan merupakan keadaan yang sangat tidak menguntungkan dan mencerminkan penegakan hukum yang lemah dan tidak optimal, sehingga berdampak kepada eksistensi tindak pidana diwilayah perairan laut dengan frekuensi yang cukup tinggi dan tetap terus berlangsung. Selain menimbulkan konflik kewenangan, keadaan ini juga merupakan kelemahan dalam hukum acara, dimana pengaturan kewenangan yang demikian ini memberikan celah yang jelas dalam proses pidana untuk melakukan praperadilan guna menguji keabsahan kewenangan penyidik yang melakukan proses penyidikan sehingga proses peradilan menyita waktu yang lama. Sementara itu sering dipermasalahkan tindakan hukum berupa penangkapan, penahanan dan penyidikan yang dilakukan penyidik.

Permasalahan lain adalah obyek penegak hukum sulit ditembus hukum. Obyek yang dimaksud disini adalah pelaku yang terlibat dalam kejahatan illegal fishing yaitu pelaku yang menjadi otak dari kegiatan tersebut. Terutama dalam hal ini adalah oknum Pejabat Penyelenggara Negara, oknum Aparat Penegak Hukum atau oknum Pegawai Negeri Sipil yang tidak diatur secara khusus dalam Undang-Undang tentang

\footnotetext{
${ }^{16}$ Soerjono Soekanto, Faktor-Faktor Yang Mempengaruhi Penegakan Hukum, PT. Raja Grafindo Persada, Jakarta, 2011, hal. 8 .

${ }^{17}$ Joko Sumaryono, Forum Koordinasi dan Konsultasi Operasi Keamanan Laut dan Penegakan Hukum, Majalah Patriot, Jakarta, 2007, hal. 3
} 
Perikanan tersebut. Penerapan Pasal 56 ayat (1) KUHP yang mengkualifikasikan pelaku tindak pidana sebagai orang yang melakukan, yang menyuruh melakukan dan yang turut serta melakukan perbuatan pidana dapat juga diterapkan dalam kejahatan Illegal Fishing yang melibatkan banyak pihak. Namun demikian beban pidana yang harus ditanggung secara bersama dalam terjadinya tindak pidana Illegal Fishing juga dapat mengurangi rasa keadilan masyarakat, karena dengan kualitas dan akibat perbuatan yang tidak sama terhadap pelaku turut serta, dapat dipidanakan maksimum sama dengan si pembuat menurut ketentuan Pasal 56 ayat (1) KUHP, sedangkan ternyata peranan pelaku utamanya sulit ditemukan.

Kedua, Hambatan yang berkaitan dengan sumber daya manusia aparat penegak hukum terdapat beberapa kelemahan yang melekat kepada aparat penegak hukum selaku individu dan kelembagaan, yakni: Aspek intelektual yang mendorong dan melahirkan profesionalisme (khususnya dalam penegakan hukum) patut dipertanyakan serta belum mampu mengikuti perkembangan hukum dan peraturan perundangundangan yang cenderung dinamis, motivasi dan kesejahteraan aparat penegak hukum masih rendah, sehingga tidak akan mampu memberikan arah pengabdian yang jelas, dedikasi sebagai bobot pengabdian terasa semakin menipis, oleh karena itu pandangan tentang keamanan nasional perlu digalakkan dalam rangka berpikir secara komprehensif integral, artinya bahwa penegakan hukum dan menjaga keamanan di laut menjadi tugas bersama. Sebagaimana diketahui bahwa prosedur dan tata cara pemeriksaan tindak pidana di laut sebagai bagian dari penegakan hukum di laut mempunyai ciri dan cara yang khas serta mempunyai beberapa perbedaan dengan pemeriksaan tindak pidana di darat. Hal ini disebabkan karena di laut terdapat bukan saja kepentingan nasional, akan tetapi terdapat pula kepentingan-kepentingan internasional yang harus dihormati, selian itu hampir semua tindak pidana diwilayah perairan laut merupakan tindak pidana yang terorganisir, sehingga diperluakan keterampilan hukum yang mumpuni dan professional dalam mengungkapnya. Oleh karena itu diperlukan kualitas maupun kuantitas sumber daya manusia aparat penegak hukum yang profesional dan berintegritas yang tidak hanya baik tetapi juga expert (ahli) dalam bidang hukum khususnya dalam penangan perkara.

Ketiga, Hambatan yang berkaitan dengan fasilitas dan sarana penegakan hukum. Sebagaimana diketahui bahwa Negara Kesatuan Republik Indonesia merupakan negara kepulauan yang sebagian besar wilayahnya berbentuk perairan, dimana Indonesia, dimana total luas wilayah indonesia adalah 7.9 juta $\mathrm{km}^{2}$ yang terdiri dari 1.8 juta $\mathrm{km}^{2}$ wilayah daratan dan 3.2 juta $\mathrm{km}^{2}$ wilayah laut teritorial serta 2.9 juta $\mathrm{km}^{2}$ laut perairan Zona Ekonomi Eksklusif (ZEE), dengan demikian total wilayah perairan Indonesia adalah 77\% dari seluruh luas Indonesia, atau tiga kali luas wilayah daratan Indonesia. Bahwa jumlah kapal yang dimiliki TNI Angkatan Laut, Polri dan Kapal Pengawas Perikanan untuk melaksanakan pengawasan di laut tidak sebanding dengan luas wilayah perairan yang harus diawasi yang membentang dari sabang sampai marauke. Keadaan ini menjadi semakin berat bagi aparat di laut, sebab sarana patroli yang kondisinya terbatas, dimana sistem pendorongan, bangunan kapal, peralatan navigasi dan komunikasi yang kurang memadai karena faktor usia serta profesionalisme pengawaknya. Kondisi ini sangat tidak menguntungkan mengingat perkembangan ilmu pengetahuan dan teknologi yang sedemikian pesat telah berdampak pula pada peningkatan kuantitas dan kualitas ancaman, sementara alokasi anggaran pemeliharaan kapal masih sangat minim.

Hambatan lainnya, yang berkaitan dengan prosedur penangan tindak pidana diwilayah perairan laut Indonesia. Bahwa undang-Undang No. 8 Tahun 1981 tentang Hukum Acara Pidana Indonesia yang dikenal dengan KUHAP, menganut sistem spesialisasi, differensiasi dan kompartemensasi, yaitu membedakan dan menerapkan pembagian kewenangan kepada masing-masing institusi dengan cara memisahkan secara tegas tugas dan wewenang penyidikan, penuntutan dan pemeriksaan disidang pengadilan serta pelaksanaan penetapan dan putusan pengadilan yang terintegrasi, menuju kepada sistem peradilan pidana terpadu. Oleh karena itu keberhasilan proses peradilan, ditentukan oleh bekerjanya sistem peardilan pidana, dimana tidak berfungsinya salah satu subsistem akan mengganggu bekerjanya subsistem paradilan pidana yang lain, yang pada akhirnya menghambat bekerjanya proses peradilan pidana. Dalam pemberantasan illegal fishing, terkait dengan wewenang masing-masing institusi yang secara yuridis formal diberi kewenangan untuk melakukan penyidikan, terlihat belum adanya sinergi antar institusi, meskipun telah dibentuk forum atau badan koordinasi seperti badan keamanan laut. Keadaan yang demikian ini terlihat dalam pelaksanaan operasi keamanan di laut yang lebih sering dilaksanakan sendiri-sendiri oleh masing-masing instansi, dimana hal ini sangat mempengaruhi pola operasi dan penggelaran kekuatan, oleh karena itu sangat 
mungkin terjadi di satu wilayah atau kawasan terdapat penumpukan kapal patroli sementara di wilayah atau kawasan lainya tidak ada unsur patroli.

Keadaan yang demikian ini menimbulkan permasalahan-permasalahan didalam praktek, yang disebabkan selain adanya perbedaan persepsi, tetapi juga akibat adanya egosentrisme dimana baik kepolisian, TNI Angkatan Laut, maupun Penyidik Pegawai negeri sipil perikanan merasa memiliki kewenangan sehingga upaya pemberantasan tindak pidana diwilayah perairan laut menjadi kurang efektif. Selain itu, kondisi ini juga rawan menimbulkan konflik kepentingan antar instansi penegak hukum dan tidak jarang pada tingkat pelaksana di lapangan sering berebut kapal tangkapan. Bahkan ada kapal perikanan yang sudah ditangkap dan diperiksa oleh penyidik TNI Angkatan Laut setelah dilepas karena tidak cukup bukti, kemudian ditangkap lagi oleh penyidik Kepolisian. Kondisi seperti ini merupakan bukti nyata telah terjadinya proses pelaksanaan ganda (double law enforcemen process), artinya bahwa tindak pidana yang telah dilakukan proses penyidikan oleh salah satu instansi harus dilakukan proses penyidikan kembali oleh instansi lainya yang juga berwenang menyidik tindak pidana diwilayah perairan laut.

\section{Upaya yang dilakukan}

Disadari bahwa persoalan illegal fishing ini merupakan persoalan multi-actors dalam konteks melibatkan banyak pihak (masyarakat nelayan, pemerintah dan pelaku perikanan); multi-level karena melibatkan juga aktor global (asing) khususnya yang terkait dengan konflik fishing ground, kerjasama multilateral di level sub-regional maupun regional; dan multi-mode khususnya yang terkait dengan regulasi peraturan, law enforcement, hingga penyediaan fasilitas dan prasarana pengawasan. Dengan mempertimbangkan efek ganda yang ditimbulkan dari persoalan illegal fishing seperti yang telah diuraikan sebelumnya, pemerintah harus melaksanakan dua strategi secara simultan, yaitu strategi ke dalam (internal strategy) dan strategi keluar (external strategy). ${ }^{18}$

Strategi ke dalam terdiri dari tiga strategi. Pertama, pembenahan sistem hukum dan peradilan perikanan. Lemahnya produk hukum serta rendahnya mental penegak hukum dilaut merupakan masalah utama dalam penanganan illegal fishing di Indonesia. Akan tetapi dengan disahkannya Undang-Undang RI No. 45 tahun 2009 tentang perikanan, maka diharapkan penegakan hukum di laut dapat dilakukan. Dalam UU perikanan ini sanksi yang diberikan terhadap pelaku illegal fishing cukup berat. Contohnya adalah dalam UU tersebut diwajibkan bagi setiap kapal penangkap ikan harus memiliki surat izin penangkapan ikan (SIPI). Bagi kapal berbendera Indonesia yang melanggar ketentuan itu, pengelola dan pemilik kapal bisa diancam pidana enam tahun dan denda Rp 2 miliar. Kalau pelanggaran dilakukan kapal berbendera asing, pengelola serta pemilik kapal terancam penjara enam tahun dan denda Rp 20 miliar. Selain itu, UU tersebut juga menegaskan bahwa pemeriksaan di sidang pengadilan dapat dilaksanakan tanpa kehadiran terdakwa. Hakim juga harus sudah menjatuhkan putusan paling lama 30 hari terhitung sejak tanggal penerimaan pelimpahan berkas perkara dari penuntut umum. Jangka waktu yang sama berlaku pula bagi hakim pengadilan tinggi serta Mahkamah Agung dalam memutuskan permohonan banding dan kasasi. Dengan kata lain penanganan pengadilan perikanan dapat dilakukan secara cepat dan efisien mengingat karakteristik komoditas perikanan yang cepat busuk. Dengan pengadilan ad-hoc ini diharapkan nilai ikan yang dapat diselamatkan dapat meningkat sekaligus membantu mengurangi kerusakan kapal asing yang dijadikan bahan sitaan, yang bisa disumbangkan kepada nelayan nasional. Adanya UU perikanan ini harus didukung oleh para aparat penegak hukum di laut, dengan armada yang tangguh serta mental dan semangat untuk menegakan hukum merupakan kunci utama implementasi UU perikanan guna mengatasi permasalahan illegal fishing.

Kedua, Peningkatan aparatur penegak hukum dengan cara pengembangan dan penguatan kamampuan pengawasan (penegakan hukum) dilaut, dapat dilakukan melalui beberapa hal yaitu (a) pemberlakuan sistem MCS (Monitoring, Control and Surveillance) di mana salah satunya adalah dengan menggunakan VMS (Vessel Monitoring Systems) seperti yang direkomendasikan pula oleh FAO. Secara sederhana sistem ini terdiri dari sistem basis data yang berbasis pada sistem informasi geografis (SIG), sehingga operator VMS dapat memantau seluruh posisi kapal di wilayah perairan tertentu. Dengan demikian keberadaan kapal penangkap ikan asing dapat segera diidentifikasi untuk dapat diambil tindakan selanjutnya. (b)

\footnotetext{
${ }^{18} \mathrm{http} / / /$ rokhmindahuri.info/2012/10/04/selamatkan-indonesia-dari-iuu-fishing/, diakses tanggal 5 Januari 2018.
} 
Memberdayakan dan meningkatkan kapasitas kelembagaan dan organisasi pengawasan yang berada di masyarakat (community-based monitoring). Dengan upaya peningkatan kesadaran akan pentingnya sumberdaya perikanan dan kelautan bagi kehidupan mereka dan kelestarian ekosistem, diharapkan nelayan lokal dapat mengawasi daerah penangkapannya dari upaya-upaya destruktif maupun illegal fishing. Sistem pengawasan berbasis masyarakat ini pun dilakukan di negara-negara maju. Jepang misalnya, telah lama menerapkan sistem ini khususnya yang terkait dengan implementasi "gyogyou ken" (fishing right) bagi komunitas perikanan tertentu. Dengan ujung tombak "gyogyou kumiai" (fisheries cooperative), komunitas perikanan lokal mengawasi daerah penangkapannya dari illegal fishing. (c) Pemenuhan kebutuhan sarana dan prasarana pengawasan secara bertahap sesuai dengan prioritas dan kebutuhan. (d) Meningkatkan koordinasi dan kerjasama dengan instansi lintas sektor yang terkait dalam bidang pengawasan.

Ketiga, penyempurnaan sistem dan mekanisme perizinan perikanan tangkap. Jumlah kapal penangkapan ikan yang diizinkan beroperasi di suatu daerah penangkapan ikan tidak melebihi jumlah hasil tangkapan yang diperbolehkan (80\% MSY) agar usaha perikanan tangkap dapat berlangsung secara menguntungkan dan lestari. Selain itu secara bertahap tidak ada lagi izin penangkapan bagi Kapal ikan asing di perairan ZEEI. Dan yang paling penting adalah prosedur pengurusan perizinan secara transparan dan cepat. Khusus untuk mengatasi masalah kapal Ikan asing yang melakukan IUU Fishing, strategi yang dapat dilakukan adalah moratorium bagi kapal penangkap ikan asing. Pemberian ijin terhadap kapal asing untuk beroperasi di wilayah perairan Indonesia bukanlah strategi "legalisasi" kapal asing ilegal, namun justru merupakan salah satu exit strategy dari persoalan illegal fishing. Karena pemberian ijin tersebut bukan tanpa syarat. Salah satunya adalah bahwa kapal asing tersebut diharuskan untuk mendaratkan ikannya di wilayah perairan Indonesia dan negara pemilik kapal asing tersebut harus bersedia turut berkontribusi dalam pengembangan fasilitas perikanan di pusat-pusat pendaratan ikan di wilayah Indonesia.

Keempat, Peningkatan sarana prasarana yaitu penguatan (moderenisasi) armada perikanan tangkap nasional. Salah satu penyebab maraknya praktek illegal fishing di ZEEI adalah sedikitnya armada kapal ikan Indonesia yang beroperasi di daerah ZEEI dikarenakan kemampuan armada kapalnya yang rendah (kemampuan jangkauan pendek dan waktu berlayar singkat). Hal ini menyebabkan para nelayan asing dengan leluasa menangkap ikan di wilaya ZEEI. Dengan kata lain, kita harus menjadikan nelayan kita sebagai tuan rumah di lautnya sendiri.

Sedangkan strategi keluar (external strategy) terkait dengan pentingnya kerjasama regional maupun international khususnya yang terkait dengan negara tetangga. Dengan meningkatkan peran ini ada 2 manfaat sekaligus yang diperoleh. Pertama, Indonesia dapat meminta negara lain untuk memberlakukan sangsi bagi kapal yang menangkap ikan secara ilegal di perairan Indonesia seperti yang diuraikan di atas. Dengan menerapkan kebijakan anti IUU fishing secara regional, upaya pencurian ikan oleh kapal asing dapat ditekan serendah mungkin. Hal ini misalnya telah dilakukan dalam bentuk Joint Commission Sub Committee of Fisheries Cooperation antara Indonesia dengan Thailand dan Filipina guna membahas isu-isu perikanan dan delimitasi batas ZEE antar negara. Kerjasama ini juga dapat diterapkan dalam konteks untuk menekan biaya operasional MCS sehingga joint operation untuk VMS misalnya dapat dilakukan.

Kedua, dengan bergabungnya Indonesia ke dalam organisasi perikanan internasional, maka secara tidak langsung Indonesia telah menghentikan praktek "non-member fishing" yang dilakukan sehingga produk perikanan Indonesia relatif dapat 'diterima' oleh pasar internasional. Pada masa lalu, keengganan pemerintah Indonesia bergabung ke dalam organisasi perikanan regional/internasional lebih disebabkan oleh adanya kewajiban membayar member fee. Namun di saat kecenderungan global akan pentingnya memberantas praktek IUU fishing ini terus meningkat, upaya pencegahan melalui organisasi internasional ini tetap perlu dilakukan secara gradual.

\section{SIMPULAN}

Yang dimaksud dengan IUU fishing adalah kegiatan penangkapan ikan yang illegal/tidak sah, unreported/tidak dilaporkan dan unregulated/ tidak sesuai aturan. Faktor-faktor yang menyebabkan terjadinya Illegal fishing di perairan Indonesia tidak terlepas dari lingkungan strategis global terutama kondisi perikanan di negara lain yang memiliki perbatasan laut dan sistem pengelolaan perikanan di Indonesia itu sendiri. 
Dari ketentuan pidana yang diatur dalam Bab XV Undang-Undang Nomor 45 Tahun 2009 tentang Perikanan dapat dikelompokkan dari segi bentuk perbuatannya yaitu Kejahatan dan pelanggaran. 1) Bentuk perbuatan yang dikategorikan kejahatan sebagaimana diatur dalam Pasal, 84, 85, 86, 88, 91, 92, 93, 94, dan 94A. 2) Bentuk perbuatan yang dikategorikan Pelanggaran sebagaimana diatur dalam Pasal, 87, 89, 90, 95, 96, 97, 98, 99, 100, 100A, 100B, 100C, dan 100D.

Maraknya perikanan ilegal di perairan Indonesia berdampak terhadap stok ikan nasional dan global. Hal ini juga menyebabkan keterpurukan ekonomi nasional dan meningkatnya permasalahan sosial di masyarakat perikanan Indonesia. Mengenai faktor-faktor yang menghambat penegakan hukum meliputi hukum itu sendiri (sustansi hukum), aparat hukum (struktural), sarana prasarana, masyarakat dan kebudayaan.

Upaya pemerintah yang harus dilakukan dalam pemberantasan illegal fishing adalah: pembenahan sistem hukum dan peradilan perikanan, Peningkatan aparatur penegak hukum dengan cara pengembangan dan penguatan kamampuan pengawasan (penegakan hukum) dilaut, penyempurnaan sistem dan mekanisme perizinan perikanan tangkap, peningkatan sarana prasarana yaitu penguatan (moderenisasi) armada perikanan tangkap nasional, Indonesia dapat meminta negara lain untuk memberlakukan sangsi bagi kapal yang menangkap ikan secara ilegal di perairan Indonesia seperti yang diuraikan di atas, dengan bergabungnya Indonesia ke dalam organisasi perikanan internasional, maka secara tidak langsung Indonesia telah menghentikan praktek "non-member fishing" yang dilakukan sehingga produk perikanan Indonesia relatif dapat 'diterima' oleh pasar internasional.

\section{DAFTAR PUSTAKA}

Adami Chazawi, Pelajaran Hukum Pidana Stelsel Pidana, Tindak Pidana, Teori-Teori Pemidanaan Dan Batas Berlakunya Hukum Pidana, PT Rajagrafindo Persada, Jakarta, 2002.

Barda Nawawi Arief, Kapita Selekta Hukum Pidana Tentang Sistem Peradilan Terpadu, Badan Penerbit Universitas Diponegoro, Semarang, 2006.

Djoko Prakoso, Pembaharuan Hukum Pidana di Indonesia, Liberty, Yogyakarta, 2000.

Joko Sumaryono, Forum Koordinasi dan Konsultasi Operasi Keamanan Laut dan Penegakan Hukum, Majalah Patriot, Jakarta, 2007.

Romli Atmasasmita, Kapita Selekta Hukum Pidana dan Kriminologi, Mandar Maju, Bandung, 2000.

Soerjono Soekanto, Faktor-Faktor Yang Mempengaruhi Penegakan Hukum, PT. Raja Grafindo Persada, Jakarta, 2011.

Supriadi, Hukum Perikanan Di Indonesia, Sinar Grafika, Jakarta, 2011, hal. 462.

http://raypratama.blogspot.com/2012/02/pengertian jenis-jenis dan tujuan.html diakses tanggal 3 Januarii 2018.

http://ikanmania25.blogspot.com/2011/11/illegal-fishing.html, diakses tanggal 3 Januari 2018.

https://lingkunganitats.wordpress.com/2014/12/25/kasus-pencurian-ikan-di-wilayah-indonesia/\#more-1407, diakses tanggal 2 Januari 2018.

http://www.cnnindonesia.com/ekonomi/20150518201340-92-54026/ekspor-perikanan-naik-signifikan/, diakses tanggal 2 Januari 2018.

http://www.medanbisnisdaily.com/news/read/2014/11/11/128705/memberantas-ganasnya-pencurian-ikandi-perairan-indonesia/ diakses tanggal 2 Januari 2018.

http://www.djpt.kkp.go.id/index.php/profil/c/15/Apa-yang-dimaksud-IUU-fishing/?category_id=12 diakses tanggal 2 Januari 2018.

http://mukhtar-api.blogspot.com/2012/07/illegal fishing.html, diakses tanggal 2 Januari 2018.

http://rokhmindahuri.info/2012/10/04/selamatkan-indonesia-dari-iuu-fishing/, diakses tanggal 5 Januari 2018.

https://bisnis.tempo.co/read/894780/sepanjang-2017-95-kapal-illegal-ditangkap-menteri-susi/full\& view=ok, diunduh tanggal 3 Agustus 2018. 